\title{
Endoplasmic Reticulum Stress and Cancer
}

\author{
Raj Kumar Yadav', Soo-Wan Chae ${ }^{1}$, Hyung-Ryong Kim ${ }^{2}$, Han Jung Chae ${ }^{1}$ \\ 1 Department of Pharmacology and Institute of Cardiovascular Research, School of Medicine, Chonbuk National University, Jeonju, Chonbuk, Korea, \\ ${ }^{2}$ Department of Dental Pharmacology, College of Dentistry, Wonkwang University, Iksan, Chonbuk, Korea
}

\begin{abstract}
The endoplasmic reticulum (ER) is the principal organelle responsible for multiple cellular functions including protein folding and maturation and the maintenance of cellular homeostasis. ER stress is activated by a variety of factors and triggers the unfolded protein response (UPR), which restores homeostasis or activates cell death. Multiple studies have clarified the link between ER stress and cancer, and particularly the involvement of the UPR. The UPR seems to adjust the paradoxical microenvironment of cancer and, as such, is one of resistance mechanisms against cancer therapy. This review describes the activity of different UPRs involved in tumorigenesis and resistance to cancer therapy.
\end{abstract}

(J Cancer Prev 2014;19:75-88)

Key Words: Endoplasmic reticulum stress, Cancer, Unfolded protein response

\section{INTRODUCTION}

The endoplasmic reticulum (ER) is the principal intracellular organelle responsible for protein folding, translocation and post-translation modification. Disturbance in the ER environment by biochemical, physiological and pathologic stimuli causes nutrient deprivation, altered glycosylation, calcium depletion, oxidative stress, DNA damage and energy disturbance/ fluctuation, resulting in ER stress with subsequent accumulation of unfolded or misfolded proteins in the ER. These cells must overcome perturbations in ER function and ER stress to survive. If unresolved ER stress can lead to apoptosis. ${ }^{1}$ The imbalance between anti- and pro-apoptotic BCl-2 proteins due to ER stress causes an increase in transcription of Bcl2-like11 (BIM), p53 unregulated modulator of apoptosis (PUMA), NADPH oxidase activator (NOXA), and BH3-only proteins. The interactions between PUMA and Bax are promoted by ER stress, leading to the release of cytochrome $c$ and apoptosis through caspase-depen- dent cleavage of $\mathrm{p} 53 .^{2}$

In tumor cells, ER stress may restore homeostasis and make the adjacent environment hospitable for tumor survival and tumor expansion. ${ }^{3}$ Various stressful conditions such as hypoxia, nutrient deprivation, $\mathrm{pH}$ changes or poor vascularization can be growth limiting for tumor cells, and thus activate the unfolded protein response (UPR). Both nutrient starvation ${ }^{4.5}$ in tumor cells and nutrient excess under normal conditions produce ER stress. ${ }^{6.7}$ The ER is the main site for the translation of excess nutrition into metabolic and inflammatory responses. During tumorigenesis, the high proliferation rates of cancer cells require increased activities of ER protein folding, assembly and transport, which are conditions that can induce physiological ER stress. ${ }^{8}$ The ER stress response is considered cytoprotective and is involved in tumor growth and adaptation against harsh environments. ${ }^{9.10}$

Three ER stress signaling branches, inositol-requiring enzyme $1 \alpha$ (IRE1 $\alpha$ ), activating transcription factor 6 (ATF6) and pancreatic ER kinase-like ER kinase (PERK) localized in the ER, are involved

Received May 10, 2014, Revised June 7, 2014, Accepted June 7, 2014

Correspondence to: Han Jung Chae

Department of Pharmacology and Institute of Cardiovascular Research, School of Medicine, Chonbuk National University, Jeonju, Chonbuk 561-180, Korea Tel: +82-63-270-3092, Fax: +82-63-275-8799, E-mail: hjchae@jbnu.ac.kr

Copyright (C) 2014 Korean Society of Cancer Prevention

(c) This is an Open Access article distributed under the terms of the Creative Commons Attribution Non-Commercial License (http://creativecommons. org/icenses/by-nc/3.0) which permits unrestricted non-commercial use, distribution, and reproduction in any medium, provided the original work is properly cited. 
in tumorigenesis. IRE $1 \alpha$ and its down-signaling, X-box binding protein (XBP1) contribute to cancer progression. ${ }^{11} \mathrm{XBP} 1$ is increased in many human cancers such as breast cancer, hepato cellular carcinoma and pancreatic adenocarcinoma. ${ }^{11}$ Similarly, another ER stress branch, PERK/eukaryotic initiation factor $2 \alpha$ (eIF2 $\alpha$ )/ATF4, also contributes to cancer progression. ${ }^{12}$ Separately, calreticulin, an ER resident chaperone, has been localized to the cell surface in tumor cells and is related to immunogenic cell death and the localization of calreticulin on the surfaces of tumor cells. This relationship may be associated with ER stress induction in tumor cells. ${ }^{13,14}$

ER stress is a potential target for developing drugs that interfere with specific signaling pathways to reduce adaptation to hypoxia, inflammation, and angiogenesis, thereby overcoming drug resistance. ${ }^{15}$ Several anti-cancer agents have recently been studied in relation to ER stress, which may directly or indirectly affect tumors. ${ }^{16}$ However, specific targets in cancer cells are not established. The effects of these drugs on nontumorigenic cells remain under investigation. ${ }^{9}$ Even during treatment with ER stress-inducing anticancer agents, tumor cells might paradoxically be more resistant than normal cells.

Tumor cells grow continuously and require effective highenergy producing systems due to their high proliferation characteristic compared with nontumorigenic cells. Therefore, glycolysis is substantially greater in tumor cells than in nontumorigenic cells. ${ }^{17-20}$ Hypoxia inducible factor $1 \alpha$ (HIF $1 \alpha$ ) plays an important role in tumor development and helps mediate angiogenesis, proliferation and invasiveness, as well as regulating the expression of glycolytic enzymes. Therefore, blocking the HIF1 $\alpha$ signal might be a novel and promising therapeutic target for the treatment of hypoxic tumors. ${ }^{21}$

The regulation/inhibition of ER chaperones or one arm of the UPR components, such as ATF4, XBP1, and PERK, have been recently suggested as potential cancer therapies. ${ }^{22,23}$ Glucose regulated protein 78 (Grp78), an ER chaperone, and UPR components are over-expressed in several tumor types such as breast, lung, hepatocellular, brain, colon, ovarian, glioblastoma, and pancreatic cancers. In a human tumor xenograft mouse model, ER stress exhibited pro-survival effects on tumor development and progression. Other ER resident proteins that participate in tumor survival include ATF4, which is increased in severe hypoxic conditions in human breast cancer tissues, ${ }^{24,25}$ and spliced XBP1, which is increased in breast cancer, lymphoma and glioblastoma cells. PERK also supports beta cell proliferation and promotes angiogenesis in human tumor xenograft mice. ${ }^{26}$

However, the ER stress response is also directly involved in proapoptotic mechanisms in either UPR-dependent or -independent manners. ${ }^{27}$ ER stress inducing agents are also potential anticancer therapies. ${ }^{28,29}$ The cytosolic domain of IRE1 $\alpha$ interacts with the Bax/Bak apoptotic pathway to induce IRE1 $\alpha$ activation. ${ }^{30}$ EI24/PIG8, a novel ER-localized Bcl2-binding protein, modulates Bcl-2 function and suppresses breast cancer invasiveness. ${ }^{31}$ Bim also mediates breast cancer-derived $\mathrm{MCF}-7$ cell death through the activation of ER stress-induced apoptosis. ${ }^{32}$ ER stress causes spontaneous tumor cell apoptosis, which has been implicated in B cell chronic lymphocytic leukemia. ${ }^{28}$ The activation of the CHOP-GADD34 axis is another potential anti-tumor strategy. ${ }^{33,34}$ PERK is well-supported as a major factor in ER stress-induced cell death, as CHOP is the downstream target of PERK. ${ }^{35}$ It has been reported that cells and live mice gain resistance to ER stress due to loss of CCAAT/enhancer binding protein homologous protein (CHOP), suggesting that CHOP stimulates the cell death program. ${ }^{36}$ Similarly, CHOP induces cell death by promoting protein synthesis and oxidation in ER stress-exposed cells. ${ }^{35,37}$

\section{UNFOLDED PROTEIN RESPONSE}

The UPR is cytoprotective as well as being cytotoxic, depending on cell status. The purpose of the UPR is to balance the ER folding environment under ER stress. If ER stress is prolonged and the UPR fails to restore ER homeostasis, tumor cells will undergo cell death. The UPR can also protect tumor cells from apoptosis in conjunction with induced tumor dormancy and permitting regrowth of the tumor when favorable conditions have been restored. 38,39

Through the UPR process, cells seek to maintain appropriate folding processes in the ER by the dissociation of Grp78/binding immunoglobulin protein (Bip), a main chaperone protein, from 3 membrane-bound ER stress sensors, including PERK, ATF6, and IRE $1 \alpha{ }^{40}$ After the dissociation of sensing proteins from Grp78/ Bip (Fig. 1), activation of these sensors occurs sequentially with PERK which blocks general protein synthesis by phosphorylating eIF2 $\alpha$, being the first. ${ }^{41-43}$ These processes also lead to inhibition of the transcription factor NF- $\mathrm{B}$ during cellular stress. ATF6 is another transcription factor that is activated by translocation to the Golgi apparatus, where ATF6 is cleaved and the active form of the transcription factor is released to regulate gene expression. ${ }^{44}$ After the activation of IRE-1 and its downstep, the splicing of $\mathrm{XBP} 1$, the spliced XBP1 protein translocates to the nucleus and activates the transcription of genes encoding chaperones or folding enzymes involved in protein folding, secretion or ERassociated protein degradation (ERAD). ${ }^{45,46}$ During tumorige- 


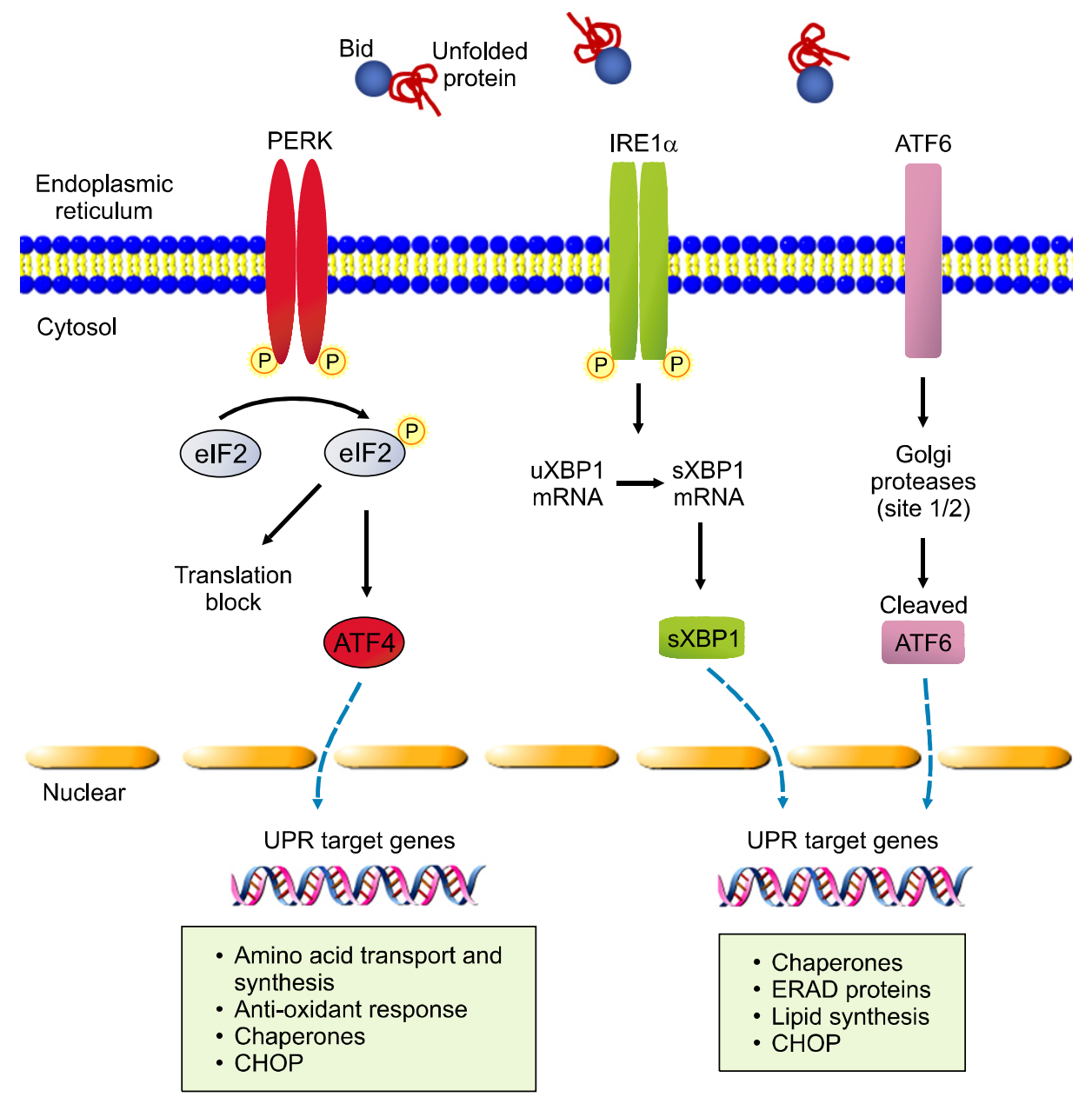

Figure 1. During endoplasmic reticulum (ER) stress, glucose regulated protein 78 binds to misfolded proteins, activating inositol-requiring enzyme $1 \alpha$ (IRE1 $\alpha$ ), activating transcription factor 6 (ATF6) and pancreatic ER kinase-like ER kinase (PERK). PERK is activated by dimerization and autophosphorylation and phosphorylates eukaryotic initiation factor $2 \alpha$ (elF2 $\alpha$ ). Phosphorylated elf $2 \alpha$ inhibits protein synthesis and activates the transcription of ATF4, inducing the transcription of downstream genes. IRE $1 \alpha$ produces a spliced form of XBP1 (XBP1s) due to its RNase activity. IRE1 assists protein folding and degradation. ATF6 translocates from the ER to the Golgi apparatus, where it is cleaved by protease activity, forming active nuclear ATF6 (N). CHOP, CCAAT/enhancer binding protein homologous protein, ERAD, ER-associated protein degradation. nesis, there is rapid tumor growth and inadequate vascularization leading to microenvironmental stress (Table 1$){ }^{47}$

\section{CANCER}

Cancer cells continuously divide and therefore tumor cells can be challenged by restricted supplies of nutrients and oxygen and decreased vascularization. Thus, ER resident proteins display altered expression patterns in cancer. ER stress has a dual impact on tumors. First, it has adaptive meaning, enhancing tumor growth. Second, it also has cytotoxic effects, inducing apoptosis. Cancer cells adapt to the surrounding microenvironment by the activation of UPR and macrophages create more favorable microenvironments for cancer cell development and invasiveness by secreting cytokines, growth factors and angiogenic factors. ${ }^{48}$ Mahadevan et al. ${ }^{49}$ described cross-talk between macrophages and cancer cells and documented such cross-talk between cancer cells. During ER stress, cancer cells induce cyclooxygenase-2 expression through NF- $\kappa \mathrm{B}$ pathways, playing antiapoptotic roles.
It also enhances pro-inflammatory NF- $\kappa \mathrm{B}$ activation via $\mathrm{CHOP}$ and maintains production of IL-8 in human epithelial cells. ${ }^{50.51} \mathrm{ER}$ stress is one of multiple pathways through which apoptosisis induced. The caspase-12 family of proapoptotic cysteine proteases plays a major role in ER stress-induced apoptosis, associated with the ER membrane, but is not activated by other non-ER stimuli. ${ }^{52}$ Grp78 expression is increased on the endothelial surface by vascular endothelial growth factor (VEGF) and enhances endothelial cell proliferation and angiogenesis. Knockdown of Grp78 suppresses endothelial cell proliferation through mitogen-activated protein kinase (MAPK) signaling. ${ }^{53}$ Cells remain in a G0-like quiescent state through the action of P38MAPK ${ }^{54,55}$ In this quiescent state, the cells are resistant to drugs that damage DNA. PERK-elf2 $\alpha$ also arrests the growth of cells at G0/G1 and inhibits tumorigenesis in subcutaneous xenograft models and a chicken embryo chorioallantoic membrane system (Fig. 2). ${ }^{56}$ 
Table 1. Endoplasmic reticulum stress markers that are increased in cancer

\begin{tabular}{|c|c|c|c|}
\hline Cancer type & Sample type & ER stress marker expression & References \\
\hline \multirow[t]{4}{*}{ Breast } & $\begin{array}{l}\text { Human breast cancer tissues and breast } \\
\text { carcinoma cell lines (MCF-7, MDA-MB-231, } \\
\text { HS578T, and HCC1500 cells) }\end{array}$ & High levels of mRNA and protein Bip/Grp78 & 66,143 \\
\hline & MCF7 cells & Increased ATF4 in severe hypoxia & 24,25 \\
\hline & Human breast cancer tissues & $\begin{array}{l}\text { Higher levels of unspliced XBP1 mRNA favoring } \\
\text { apoptosis of tumor cells and higher levels of } \\
\text { spliced XBP1 mRNA increasing tumor survival }\end{array}$ & 106 \\
\hline & $\begin{array}{l}\text { Human breast cancer hormone-resistant cells, } \\
\text { MCF-7/BUS-10 }\end{array}$ & $\begin{array}{l}\text { Hormone-resistant breast cancer cells promote } \\
\text { Grp78 to the cell surface, which can be further } \\
\text { elevated by ER stress }\end{array}$ & 144 \\
\hline Prostate & $\begin{array}{l}\text { Human prostate adenocarcinoma } \\
\text { hormone-resistant cells, C4-2B }\end{array}$ & $\begin{array}{l}\text { Hormone-resistant prostate cancer cells promote } \\
\text { Grp78 to the cell surface, which can be further } \\
\text { elevated by ER stress }\end{array}$ & 144 \\
\hline Pancreatic & Human tumor xenograft mice & $\begin{array}{l}\text { PERK supports beta-cell insulinoma proliferation } \\
\text { and promotes angiogenesis }\end{array}$ & 145 \\
\hline Liver & $\begin{array}{l}\text { Human hepatocellular carcinoma tissues, human } \\
\text { hepatocellular carcinoma cells SMMC7721 }\end{array}$ & $\begin{array}{l}\text { Grp78 promotes the invasion of hepatocellular } \\
\text { carcinoma both in vitro and in vivo }\end{array}$ & 73 \\
\hline Lymphoma & Patient & $\begin{array}{l}\text { Splicing of XBP1 promotes tumor growth under } \\
\text { hypoxic conditions }\end{array}$ & 146 \\
\hline \multirow[t]{3}{*}{$\begin{array}{l}\text { Brain, central nervous } \\
\text { system }\end{array}$} & $\begin{array}{l}\text { Human brain tumor specimens, glioma cell lines } \\
\text { A172, U87, LNZ308, U251, LN-443, and LN-229 }\end{array}$ & Grp78 is overexpressed & 65 \\
\hline & U373 glioblastoma cells & $\begin{array}{l}\text { XBP-1 depletion dramatically sensitized U373 cells } \\
\text { to viral oncolysis }\end{array}$ & 147 \\
\hline & Glioblastoma patient samples & Inhibiting IRE $1 \alpha$ enhances oncolytic therapy & 147 \\
\hline \multirow[t]{2}{*}{ Colorectal } & HT29 cells & Increases ATF4 in severe hypoxia & 25 \\
\hline & $\begin{array}{l}\text { Human colon carcinoma HT29, SW480, SW620, } \\
\text { DLD1, and Lovo cell lines }\end{array}$ & $\begin{array}{l}\text { Grp78 is found on CRC cell surfaces and promotes } \\
\text { CRC cell migration and invasion }\end{array}$ & 148 \\
\hline Ovarian & Patients & Grp78 is overexpressed & 149 \\
\hline
\end{tabular}

ER, endoplasmic reticulum; Bip, binding immunoglobulin protein; Grp78, glucose regulated protein 78; ATF4, activating transcription factor 4; XBP1, X-box binding protein; PERK, pancreatic ER kinase-like ER kinase; IRE1 $\alpha$, inositol-requiring enzyme 1; CRC, colorectal cancer.

\section{Glucose regulated protein $78 /$ binding immuno- globulin protein in cancer}

The ER chaperone protein Grp78 is one of the most active components of cancer cells and is overexpressed in different kinds of cancers. ${ }^{57.58}$ It has been interpreted as a chaperone protein that enhances cancer cell adaptation against hypoxic environments and as a resistance protein against anti-cancer therapy. ${ }^{59,60}$ Grp78 regulates cell apoptosis, proliferation, invasion, inflammation and immunity, especially in cancer systems. ${ }^{61}$ Recently, it has also been shown to be involved in tumorigenesis, metastasis, and angiogenesis. ${ }^{8,62,63}$ The expression of Grp78 is correlated with both the rate of patient survival and the depth of tumor invasion. In human cancers, elevated Grp78 levels indicate higher pathologic grade, recurrence risk, and poor patient survival in breast, liver, prostate, colon, and gastric cancers, although lung cancer is an exception to these outcomes. ${ }^{8}$ In the ER, Grp78 inhibits BIK-mediated apoptosis via physical and functional interactions with $\mathrm{BIK}$, and confers resistance to estrogen starvation-induced apoptosis in human breast cancer cells. ${ }^{64}$ It has been also shown that overexpression of Grp78 decreases the sensitivity of glioma cells to etoposide and cisplatin. ${ }^{65}$ Indeed, some studies indicate that ER chaperones Grp78 and Grp94 are effective biomarkers that indicate aggressive behavior and poor prognosis in cancer. ${ }^{66-69}$

Grp78 expression is also positively correlated with increasing tumor thickness and with increasing dermal tumor mitotic index, ${ }^{70}$ suggesting the potential to target Grp78 for cancer therapy. A Grp78-knockout model and Grp78 siRNA-transfected human prostate cancer cells showed that protein kinase B activation is reduced in phosphatase and tensin homolog-null prostate epithelium, reducing cancer development ${ }^{71,72}$ Grp78 is suggested to be a novel approach to reducing tumorigenesis. ${ }^{23}$ Overexpression of Grp78 leads to invasion activity in hepatocellular cancer. ${ }^{73}$ Focal adhesion kinase (FAK) is involved in adhesion, invasion and migration activity, and overexpression of Grp78 increases the phosphorylation of FAK (PY397) and induces invasion by phosphorylating p190RhoGAP and inhibiting Rock kinase. ${ }^{73}$ The 


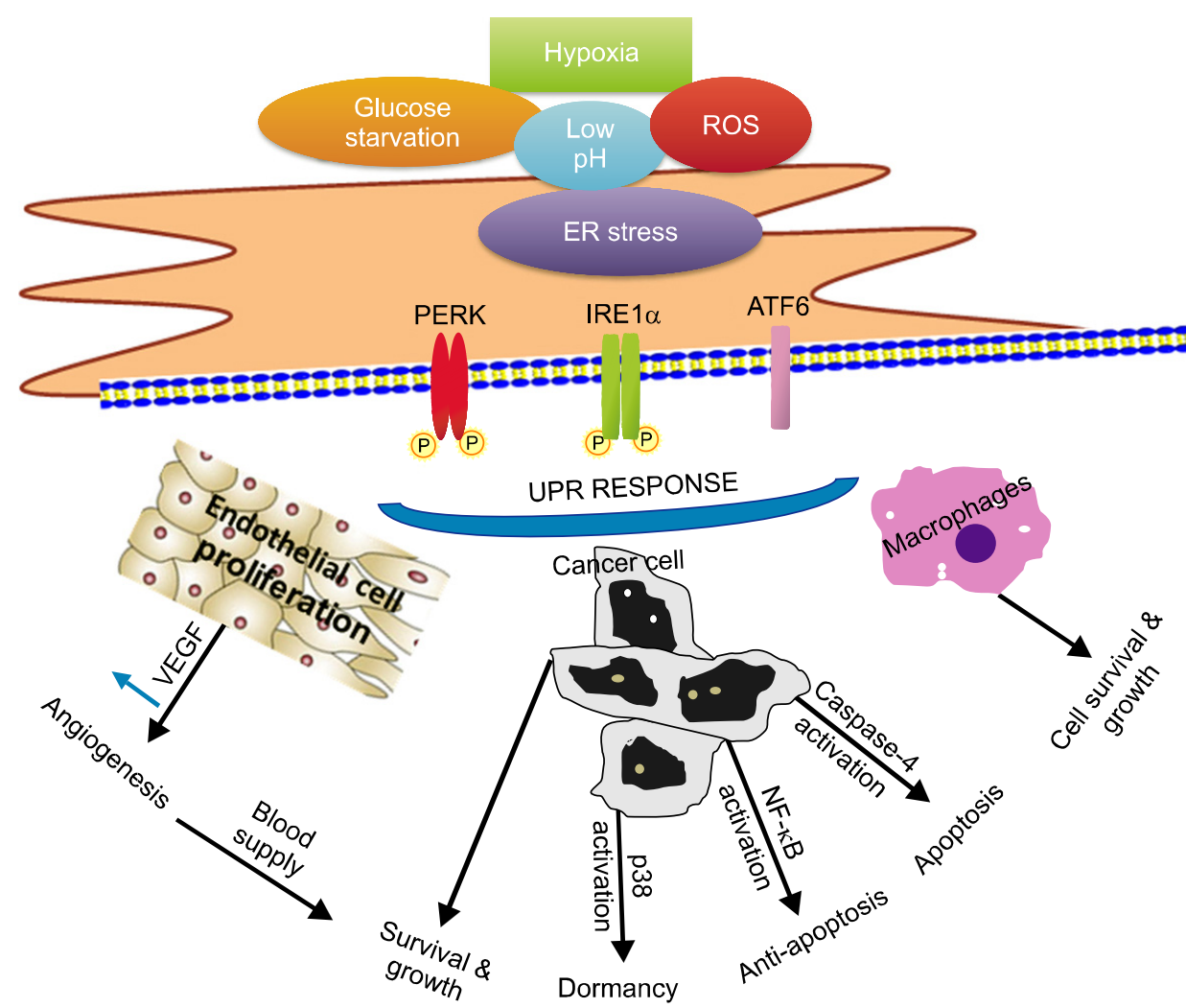

Figure 2. Cancer cells grow continuously, develop decreased nutrition supplies and increase reactive oxygen species (ROS) production, thereby inducing hypoxia and activating endoplasmic reticulum (ER) stress. ER stress activates the unfolded protein response (UPR). The UPR is both apoptotic and adaptive in tumor cells. The adaptive activity of UPR induces anti-apoptotic NF-KB, which inhibits p53 dependent apoptotic signals and induces angiogenic activity through increased vascular endothelial growth factor (VEGF) secretion. Mitogen-activated protein kinase (p38 MAPK) contributes to tumor cell dormancy during drug treatment through pancreatic ER kinase-like ER kinase (PERK)-eukaryotic initiation factor $2 \alpha$, which arrests the growth of cells at GO/G1. Tumor-associated macrophages also secrete inflammatory cytokines that promote tumor growth, angiogenesis, invasion and metastasis during periods of ER stress. IRE1 $\alpha$, inositol-requiring enzyme $1 \alpha$; ATF6, activating transcription factor 6 . phosphorylation of FAK facilitates invasion by activating the urokinase-type plasminogen activator system. ${ }^{74}$ Grp78 translocates to the colorectal cancer cell surface, interacting with betal-integrin and facilitating the cell-matrix adhesion process. ${ }^{73}$ Insulin-like growth factor binding protein-3 stimulates the survival of breast cancer cells through interaction with Grp78. ${ }^{75}$ Recently, the cytotoxic effects of Grp78 knockdown were confirmed in many cancer cell lines. ${ }^{76,77}$ Specific Grp78 inhibitors have also been screened as anticancer agents, ${ }^{78.80}$ suggesting that Grp78/Bip inhibition is a promising anti-cancer strategy. In addition, the possible translocation of Grp78 in cancer cells has been studied as a possible cancer treatment. Grp78 is primarily located inside the ER, but during ER stress, Grp78 may be translocated to the surface of tumor cells. ${ }^{57.81}$ During ER stress, some fraction of Grp78 resides in the cytosol, nucleus and mitochondria in addition to the ER. ${ }^{82.83}$ The inhibition of Grp78 translocation is another promising potential anticancer strategy.

\section{Pancreatic endoplasmic reticulum kinase-like endo- plasmic reticulum kinase in cancer}

PERK/eIF2 $\alpha$ plays regulatory roles in tumor initiation and survival, thereby facilitating adaptation in different situations such as hypoxia and oxidative stress. ${ }^{3.984,85}$ Tumor cells grow rapidly, leading to the formation of new vasculature and finally linking to microenvironment and nutrient deprivation conditions. Increased demand for glucose and oxygen leads to cytotoxic conditions. As the production of ATP by glycolysis and NADPH in a reducing equivalent form is disturbed, reactive oxygen species (ROS) are generated. In the mitochondria, ROS accumulate and cause activation of ER stress. ${ }^{86,87}$ The ER responds to alterations in nutrient deficiency with a cellular stress sensor that is associated with tumorigenesis. PERK is a trans-ER membrane serine/ threonine protein kinase that contains an N-terminal ER luminal domain and a cytoplasmic $\mathrm{C}$-terminal protein kinase domain. ${ }^{88}$ Nrf2 transcription factor ${ }^{89}$ and elF2 $\alpha$ are the 2 transcription factors that are phosphorylated by PERK. The phosphorylation of elF2 inhibits the translation of most transcripts, simultaneously increasing the translation of selected mRNAs such as ATF4 transcription factor. ${ }^{90.91} \mathrm{Nrf2}$ is phosphorylated by PERK and is released from an inhibitory E3 ligase complex containing Keap1 and cullin 3 and translocated into the nucleus, where it produces enzymes responsible for the elimination of intracellular ROS. ${ }^{92-95}$ Thus, PERK is one of the key factors maintaining cellular redox homeostasis and reducing ROS-induced genotoxic stress. PERK has been considered to be a regulator of the growth of cancerous cells. A previous study examined whether the absence of PERK affected the ability of mammary carcinoma cells to form solid tumors in vivo. ${ }^{96}$ Hypoxia is the most common feature of tumors, 
downregulating protein synthesis by PERK inhibition and phosphorylation of elF2 $\alpha$ at Ser51. When hypoxia occurs in tumors, the transcription regulator HIF $1 \alpha$ is stabilized and fully activates the complete branch of UPR, i.e., PERK, leading to the phosphorylation of elf2 $\alpha$, ATF4, and GADD34. The phosphorylation of elf $2 \alpha$ inhibits general protein synthesis, but ATF4, a transcription factor, is related to cancer cell proliferation and survival against nutrient deprivation through amino acid synthesis. $^{84}$

\section{Inositol-requiring enzyme $1 \alpha / \mathrm{X}$-box binding pro- tein in cancer}

IRE1 $\alpha$, an ER transmembrane sensor, plays a protective role against ER stress in cells and tissues. ${ }^{1}$ During ER stress, IRE1 $\alpha$ is activated by oligomerization and autophosphorylation, resulting in the activation of its endoribonuclease to cleave and initiate splicing of the XBP1 mRNA. ${ }^{97}$ IRE1 $\alpha$-dependent decay of mRNAs (RIDD) helps to restore ER homeostasis by targeting mRNAs encoding secretory proteins and is distinct from XBP1 splicing. The activity of RIDD is regulated by IRE1 $\alpha$ RNase activity. ${ }^{98}$ RIDD has been the subject of very few studies, and further examinations of the mechanism of its pathway in apoptosis are necessary, due to the relatively new discovery of its role in ER stress. The IRE1 $\alpha$-XBP1 pathway has been also considered for a pro-survival role in the UPR. ${ }^{97}$ However, under conditions of prolonged and uncompensated stress, the UPR leads to cellular apoptosis. ${ }^{99}$ Another suggested pathway is IRE1 $\alpha$-TRAF2-ASK. IRE1 $\alpha$ is activated by phosphorylation, binds to tumor-necrosis factor receptor associated factor 2 (TRAF2) and activates apoptosis signal-regulating kinase (ASK1), leading to the activation of JNK and p38 and ER-stressed induced cell death. ${ }^{100,101}$ IRE1 $\alpha$ and TRAF2 pathwaysare also involved in mitochondria-independent apoptotic response by directly activating procaspase- $4 .{ }^{102}$

A number of recentstudies have suggested that IRE1 $\alpha / \mathrm{XBP} 1$ is essential for the maintenance of malignancy under oncogenic stress. XBP1-lacking cells displayan inability to grow in tumor xenograft mouse models. ${ }^{103,104}$ Instead, XBP1-deficient cells exhibit increased apoptosis and decreased clonogenic survival under ER stress orhypoxia. Furthermore, expression of the dominant-negative form of IRE1 $\alpha$ or inhibition of XBP1 gene expression reduce blood vessel formation during tumorigenesis. ${ }^{105}$ However, the expression of spliced XBP1 restores angiogenesis in IRE1 $\alpha$ dominant-negative expressing cells, suggesting that UPR signaling through IRE1 $\alpha / \mathrm{XBP} 1$ is crucial for angiogenesis in the early stages of tumor development. High expression levels of spliced XBP1 are associated with increased tumor survival, whereas high levels of the unspliced form of XBP1 increase the apoptosis of tumorcells. ${ }^{106}$ IRE1 $\alpha$ also regulates the expression of cyclin A1 and promotes cell proliferation by splicing XBP1 in prostate cancer, andis related to the cancer suppressor, p38MAPK. XBP1-deficient cells produce less catalase than normal cells, increasing ROS generation and p38 activation. ${ }^{107}$ The IRE1 $\alpha$-XBP1 pathway has recently been suggested as an appealing target for cancer therapy. ${ }^{97}$ However, the specific role of IRE1 $\alpha$ in tumor characteristics such as growth and angiogenesis has not been clarified. ${ }^{108}$

\section{THE THERAPEUTIC POTENTIAL OF TARGETING ENDOPLASMIC RETICULUM STRESS-ASSOCIATED MACHINERY}

\section{Targeting unfolded protein response}

The importance of UPR in the maintenance of malignancy has inspired great interest in exploring the therapeutic potential of targeting UPR components. Tumor cells grow under oncogenic stress caused by hypoxia, nutrient deprivation, DNA damage, metabolic stress, and oxidative stress, leading to UPR as an adaptation strategy. ${ }^{109}$ However, most normal cells are not subjected to stress and the UPR pathways remain inactive in these cells.

This difference between tumor and nontumorigenic cells might offer an advantage of targeting the UPR to achieve specificity in cancer therapy (Table 2). ${ }^{110}$ If tumor cells are exposed to another form of ER stress, the intensity of the stress might be a threshold, thereby inducing specific cell death in tumor cells, with less effect on nontumorogenic cells. ER stress inducing mechanisms are also potential anti-cancer strategies through disturbing the adaptive response of UPR. A strategy of diminishing or removing UPR may also solve the problem of drug resistance against anti-cancer agents. Therefore, cancer therapeutic approaches might be divided into 2 categories: (1) increasing misfolded proteins in ER to overload protein folding requirements, therefore inducing more severe ER stress and cell death, and (2) inhibiting UPR adaptive and pro-survival pathways, leading to increased sensitivity to anticancer therapy. ${ }^{110}$

\section{Targeting protein degradation machinery}

Misfolded proteins in ER are identified by molecular chaperones and lectin-like proteins in the ERAD pathway and are subsequently degraded by ERAD as a part of the ER quality control mechanism. In cancer cells, there is continuous activation of 
Table 2. Endoplasmic reticulum stress-/unfolded protein response-targeted drugs that inhibit cancer development

\begin{tabular}{|c|c|c|c|}
\hline Therapeutic drugs & Therapeutic effect related to ER stress & Indication & References \\
\hline Irestatin & Inhibits IRE $1 \alpha$ activity & Malignant myeloma cells & 110 \\
\hline Honokiol (HNK) & $\begin{array}{l}\text { Binds to the unfolded ATPasedomain } \\
\text { of GRP78 with consequent induction of } \\
\text { ER stress }\end{array}$ & Melanoma, glioblastoma & 134 \\
\hline Bortezomib A & $\begin{array}{l}\text { Induces ER stress by inhibiting a } 26 \mathrm{~S} \\
\text { proteasome and thereby activating the } \\
\text { ER-associated degradation pathway } \\
\text { with misfolded proteins }\end{array}$ & Different types of cancer & $150-152$ \\
\hline Retaspimycin (IPI-504) & Inhibits HSP90 activities & $\begin{array}{l}\text { Gastrointestinal stromal tumors, non-small } \\
\text { cell lung, prostate }\end{array}$ & 153 \\
\hline SNX-2112 & Inhibits HSP-90 activities & Gastric cancer & 154 \\
\hline MG-132 & Inhibits $26 \mathrm{~S}$ proteasome & Different types of cancer & $151,155,156$ \\
\hline Ritonavir & $\begin{array}{l}\text { HIV protease inhibitor, activates certain } \\
\text { UPR components such as CHOP and } \\
\text { Grp78 }\end{array}$ & $\begin{array}{l}\text { Improves the antibody response and } \\
\text { inhibits } \mathrm{CD} 8+\mathrm{T} \text { cell activity }\end{array}$ & 9,121 \\
\hline $\begin{array}{l}\text { Epidermal growth factor } \\
\text { (EGF)-SubA }\end{array}$ & GRP78 targeting cytotoxin & Prostate tumor & 79 \\
\hline GSK2656157 & $\begin{array}{l}\text { Inhibits PERK and eIF2 } \alpha \text { phosphorylation, } \\
\text { ATF4 translation and CHOP mRNA } \\
\text { expression }\end{array}$ & Multiple myeloma, pancreatic cancer & 139 \\
\hline Brefeldin A (BFA) & $\begin{array}{l}\text { Inhibits protein transport from ER to } \\
\text { Golgi complex }\end{array}$ & Cancer, leukemia & $14,150,157$ \\
\hline $\begin{array}{l}\text { Delta(9)-tetrahydrocannabinol } \\
\text { (THC) }\end{array}$ & $\begin{array}{l}\text { Increases phosphorylation of eIF2 } \alpha \text { and } \\
\text { activates ER stress response }\end{array}$ & Glioma cells & 140 \\
\hline Resveratrol & $\begin{array}{l}\text { Resveratrol induces GRP78 and CHOP, } \\
\text { p-eIF2 } \alpha \text { and XBP1 splicing }\end{array}$ & Human leukemia K562 cell line & 141 \\
\hline $\begin{array}{l}\mathrm{O}(2) \text {-[2,4-dinitro-5-(N-methyl-N-4-ca } \\
\text { rboxyphenylamino)phenyl]1-(N,N- } \\
\text { methylamino) diazen-1-ium-1,2- } \\
\text { diolate }(\mathrm{PABA} / \mathrm{NO})\end{array}$ & $\begin{array}{l}\text { PDI inhibitor, leads to activation of } \\
\text { PERK, eIF2 } \alpha \text {, XBP1 splicing, BiP, PDI, } \\
\text { GRP94, and ERO1 }\end{array}$ & $\begin{array}{l}\text { Human leukemia (HL60), ovarian cancer } \\
\text { cells (SKOV3). }\end{array}$ & 142 \\
\hline
\end{tabular}

ER, endoplasmic reticulum; IRE1 $\alpha$, inositol-requiring enzyme 1 $\alpha$; GRP78, glucose regulated protein 78; HSP90, heat shock protein 90; HIV, human immunodeficiency virus; UPR, unfolded protein response; CHOP, CCAAT/enhancer binding protein homologous protein; PERK, pancreatic ER kinase-like ER kinase; eIF2 $\alpha$, eukaryotic initiation factor $2 \alpha$; XBP1, X-box binding protein; PDI, protein disulfide isomerase; BiP, binding immunoglobulin protein; ERO1, ER oxidoreductin-1.

ERAD, clearing misfolded proteins. Proteasomal activation is a main pathway for ERAD. ${ }^{5}$ Proteasome inhibitors have been intensively studied in the treatment of cancers. Bortezomib (Velcade; PS-341) is a highly selective and reversible proteasome inhibitor that has been approved for clinical use against multiple myeloma and as a single agent or in combination with chemotherapeutics against solid tumor malignancies. ${ }^{11,112}$ In vitro studies have confirmed the cytotoxic effects of bortezomib on various kinds of cancer cells, including those of the prostate, lung, breast, and colon. ${ }^{113-115}$ Although the mechanisms involved in its anticancer activity are still in the process of being elucidated, bortezomib was recently shown to cause accumulation of misfolded proteins in ER and apoptosis by inhibiting 26S proteasome activity and subsequent ERAD machinery ${ }^{116,117}$; moreover, bortezomib was shown to inhibit IRE1 $\alpha$ endoribonuclease/kinase activity. ${ }^{45,18}$ In the ERAD process, a cytosolic ATPase, p97, plays key roles in extracting misfolded proteins that are poly ubiquitinated and transporting them to the proteasome for degradation. Like bortezomib, Eeyarestatin I (EerI), achemical inhibitor that can block ERAD, induces an integrated stress response in the ER,leading to cell death. EerI activates CREB/ATF transcription factors ATF3 and ATF4, which form acomplex capable of activating BH3-only protein NOXA expression. ${ }^{119}$ These studies suggested that the ERAD inhibitor EerI may represent a novel class of anticancer drugs that integrate ER stress response with epigenetic mechanisms to induce cell death. Recently, an ERAD chemical inhibitor designed to block the ERAD pathway has also shown cytotoxic activity against cancer. ${ }^{120}$ Ritonavir, used as a HIVprotease inhibitor, also interferes with ERAD machinery and activates UPR components such as CHOP and Grp78. ${ }^{9.121}$ 


\section{Heat shock protein 90 inhibitor}

The heat shock protein 90 (HSP90) complex is activated in cancer cells to regulate the folding and degradation of unfolded proteins. ${ }^{122}$ Cancer development-associated proteins such as Akt, Flt3, Bcr-Abl, and Apaf and cyclin-dependent kinase are regulated by the HSP9O inhibitor. All 3 branches of UPR are activated by HSP90 inhibitors such as retaspimycin (IPI-504) and SNX-2112, activating a caspase-dependent cell death pathway. ${ }^{123}$ The HSP90 inhibitor also leads to inactivation, destabilization and degradation of HSP90 client proteins. A number of drugs were discovered during the search for a HSP90 inhibitor (Table 2) such as HSP90 inhibitors and geldanamycin analogs like 17allylamino-17-demethoxygeldanamycin. Recently HSP90 was found to regulate the UPR by stabilizing IRE1 and PERK. ${ }^{124}$

\section{Brefeldin A}

Brefeldin is an $\mathrm{ADP}$ ribosylation factor (ARF) inhibitor required for coatamer assembly on the Golgi membrane. Blocking ARF blocks the retrograde transport of protein from the ER to the Golgi and causes the accumulation of trapped secretory protein in the ER, subsequently activating the UPR. Activation of the UPR results in apoptosis in many cancer cell lines such as multiple myeloma (U266, NCI-H929), Jurkat, HeLa, leukemia (HL60, K562, and BJAB), colon (HT-29), and prostate and adenoid cystic sarcoma cells. ${ }^{125-130}$ Brefeldin A may be an effective therapeutic drug. A related mechanism has been suggested to perturb intracellular protein trafficking and induce caspase activation and apoptosis through analysis of a chronic lymphocytic leukemia cell model. Brefeldin A was found to trigger Grp78 upregulation and ER dilation, markers of ER stress in follicular lymphoma cells. ${ }^{131}$

\section{Glucose regulated protein 78/binding immuno- globulin protein inhibitor}

Grp78 acts as a survival factor in solid tumor and cancer cells. ${ }^{132}$ Its expression is correlated with metastasis or late stages of tumor progress. The expression of Grp78 may be related to resistance against anticancer therapy in which apoptosis signaling is involved. $^{8}$ In cancer cells, knockdown of BiP/Grp78 increases sensitivity against therapeutic drugs. ${ }^{132}$ Epidermal growth factor-SubA (EGFSubA) is highly toxic to the growing of confluent epidermal growth factor-expressing cancer cells and Grp78, a causative protein for cancer, is rapidly cleaved following treatment with EGFSubA. ${ }^{79}$ Epigallocatechin gallate, which binds to the ATP-binding domain of Grp78, blocks its UPR protective function and sensitizes glioma cells against chemotherapeutic agents such as temozolomide or etoposide. Glucose deprived tumor cells are more sensitive to versipelostatin because they exhibit inhibited UPR. Versipelostatin inhibits BiP/Grp78 transcriptional activation in combination with cisplatin, regulating tumor growth in a stomach cancer xenograft model. ${ }^{133}$ Honokiol [2-(4-hydroxy-3-prop-2-enyl-phenyl)-4-prop-2-enyl-phenol], a cellwall component of $M$. grandiflora, exhibits similar anti-tumor activity to EGCG and has been tested for the treatment of multiple melanoma and glioblastoma ${ }^{134}$.

\section{Inositol-requiring enzyme $1 \alpha$ inhibitor}

IRE1 $\alpha$ inhibitors inhibit IRE1 $\alpha$ activity by binding at one of the 2 sites on the IRE1 $\alpha$ : the catalytic core of the RNase domain or the ATP-binding pocket of the kinase domain. Salicylaldehydes

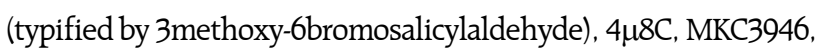
and STF083010 interact with the catalytic core of the RNAase domain and have high potential activity for IRE1 $\alpha$ RNase activity. ${ }^{97,135-137}$ Salicylaldehydes (typified by 3methoxy-6bromosalicylaldehyde) bind to IRE1 $\alpha$ in an irreversible manner and inhibit XBP1 splicing and RIDD activity. ${ }^{137}$ The $4 \mu 8 \mathrm{C}$ forms a stable imine bond at the critical lysine 907 residue in the catalytic core of the RNase domain and blocks the cleavage of XBP1 mRNA and RIDD. ${ }^{97,135.136}$ MKC-3946, in combination with a proteosome inhibitor, broteozomib, induces ER stress by inhibiting XBP1 mRNA splicing. ${ }^{97}$ STF-083010 exerts an inhibitory effect on tumors in mice bearing human multiple myeloma xenografts. ${ }^{138}$ Irestatin, an inhibitor of IRE1 $\alpha$, mediates the inhibition of XBP1s transcription activity and inhibitsthe UPR, disturbing the growth of malignant myeloma cells. ${ }^{110}$

\section{Other inhibitors}

A number of drugs are currently being screened to target different causes of cancer, with actions such as inhibiting ER signaling or activating the ER stress pathway. GSK2656157 inhibits PERK signaling and reduces cancer growth by impairing amino acid metabolism and angiogenesis. ${ }^{139}$ Delta(9)-tetrahydrocannabinol, the main active component of marijuana, induces human glioma cell death through the stimulation of autophagy. This effect is associated with increasing phosphorylation of eIF2a and activation of an ER stress response that promotes autophagy. ${ }^{140}$ Resveratrol, a natural plant polyphenol, has been reported to cause cell cycle arrest via induction of the UPR in human leukemia cell lines. ${ }^{141}$ The polyphenol stimulates transcriptional induction of Grp78 and CHOP and phosphorylation of eIF2 $\alpha$ and XBP1 splicing. Protein disulfide isomerase (PDI) is one of the most abundant ER proteins and maintains a sentinel function in the 
organization of accurate protein folding. The PDI inhibitor, $\mathrm{O}(2)$-[2,4-dinitro-5-(N-methyl-N-4-carboxyphenylamino)phenyl] 1-(N,N-methylamino) diazen-1-ium-1,2-diolate (PABA/NO), increases intracellular nitric oxide that causes S-glutathionylation of PDI. PABA/NO activates the UPR and leads to the activation of PERK, eIF2 $\alpha$, XBP1 splicing, BiP, PDI, GRP94, and ERO1 in human leukemia (HL60) and ovarian cancer cells (SKOV3). ${ }^{142}$

\section{CONCLUSION}

Accumulating evidence is helping to elucidate the role of the ER stress response in tumorigenesis and cancer resistance. These findings have raised the exciting possibility of targeting UPR components in cancer therapy and overcoming drug resistance, and may facilitate the discovery of distinct roles of UPR branches that produce survival or death signals in tumorigenesis.

\section{ACKNOWLEDGEMENTS}

This study was supported by the funding from the Korean National Research Foundation (2012R1A2A1A03001907). The authors apologize to all those investigators whose work was not cited due to oversight or space constraints.

\section{CONFLICTS OF INTEREST}

No potential conflicts of interest were disclosed.

\section{REFERENCES}

1. Tabas I, Ron D. Integrating the mechanisms of apoptosis induced by endoplasmic reticulum stress. Nat Cell Biol 2011;13: 184-90.

2. Rao RV, Niazi K, Mollahan P, Mao X, Crippen D, Poksay KS, et al. Coupling endoplasmic reticulum stress to the cell-death program: a novel HSP90-independent role for the small chaperone protein p23. Cell Death Differ 2006;13:415-25.

3. Martinon F. Targeting endoplasmic reticulum signaling pathways in cancer. Acta Oncol 2012;51:822-30.

4. Travers KJ, Patil CK, Wodicka L, Lockhart DJ, Weissman JS, Walter P. Functional and genomic analyses reveal an essential coordination between the unfolded protein response and ER-associated degradation. Cell 2000;101:249-58.

5. Tsai YC, Weissman AM. The Unfolded Protein Response, Degradation from Endoplasmic Reticulum and Cancer. Genes Cancer 2010;1:764-78.

6. Hirosumi J, Tuncman G, Chang L, Görgün CZ, Uysal KT, Maeda $\mathrm{K}$, et al. A central role for JNK in obesity and insulin resistance. Nature 2002;420:333-6.

7. Ozcan U, Cao Q, Yilmaz E, Lee AH, Iwakoshi NN, Ozdelen E, et al. Endoplasmic reticulum stress links obesity, insulin action, and type 2 diabetes. Science 2004;306:457-61.

8. Lee AS. GRP78 induction in cancer: therapeutic and prognostic implications. Cancer Res 2007;67:3496-9.

9. Healy SJ, Gorman AM, Mousavi-Shafaei P, Gupta S, Samali A. Targeting the endoplasmic reticulum-stress response as an anticancer strategy. Eur J Pharmacol 2009;625:234-46.

10. Ma Y, Hendershot LM. The role of the unfolded protein response in tumour development: friend or foe? Nat Rev Cancer 2004:4:966-77.

11. Koong AC, Chauhan V, Romero-Ramirez L. Targeting XBP-1 as a novel anti-cancer strategy. Cancer Biol Ther 2006:5:756-9.

12. Koumenis C, Naczki C, Koritzinsky M, Rastani S, Diehl A, Sonenberg N, et al. Regulation of protein synthesis by hypoxia via activation of the endoplasmic reticulum kinase PERK and phosphorylation of the translation initiation factor eIF2alpha. Mol Cell Biol 2002;22:7405-16.

13. Garg AD, Krysko DV, Verfaillie T, Kaczmarek A, Ferreira GB, Marysael T, et al. A novel pathway combining calreticulin exposure and ATP secretion in immunogenic cancer cell death. EMBO J 2012;31:1062-79.

14. Panaretakis T, Kepp O, Brockmeier U, Tesniere A, Bjorklund AC, Chapman DC, et al. Mechanisms of pre-apoptotic calreticulin exposure in immunogenic cell death. EMBO J 2009;28:578-90.

15. Kraskiewicz H, FitzGerald U. InterfERing with endoplasmic reticulum stress. Trends Pharmacol Sci 2012;33:53-63.

16. Schleicher SM, Moretti L, Varki V, Lu B. Progress in the unraveling of the endoplasmic reticulum stress/autophagy pathway and cancer: implications for future therapeutic approaches. Drug Resist Updat 2010;13:79-86.

17. Meienhofer MC, De Medicis E, Cognet M, Kahn A. Regulation of genes for glycolytic enzymes in cultured rat hepatoma cell lines. Eur J Biochem 1987;169:237-43.

18. Dang CV, Lewis BC, Dolde C, Dang G, Shim H. Oncogenes in tumor metabolism, tumorigenesis, and apoptosis. J Bioenerg Biomembr 1997:29:345-54.

19. Osthus RC, Shim H, Kim S, Li Q, Reddy R, Mukherjee M, et al. Deregulation of glucose transporter 1 and glycolytic gene expression by c-Myc. J Biol Chem 2000;275:21797-800.

20. Atsumi T, Chesney J, Metz C, Leng L, Donnelly S, Makita Z, et al. High expression of inducible 6-phosphofructo-2-kinase/fructose-2,6-bisphosphatase (iPFK-2; PFKFB3) in human cancers. Cancer Res 2002;62:5881-7.

21. Kong D, Park EJ, Stephen AG, Calvani M, Cardellina JH, Monks A, et al. Echinomycin, a small-molecule inhibitor of hypoxia-inducible factor-1 DNA-binding activity. Cancer Res 2005;65:904755.

22. Wang Y, Alam GN, Ning Y, Visioli F, Dong Z, Nör JE, et al. The unfolded protein response induces the angiogenic switch in human tumor cells through the PERK/ATF4 pathway. Cancer Res 2012;72:5396-406.

23. Luo B, Lee AS. The critical roles of endoplasmic reticulum chaperones and unfolded protein response in tumorigenesis and anticancer therapies. Oncogene 2013;32:805-18.

24. Nagelkerke A, Bussink J, Mujcic H, Wouters BG, Lehmann S, Sweep FC, et al. Hypoxia stimulates migration of breast cancer cells via the PERK/ATF4/LAMP3-arm of the unfolded protein response. Breast Cancer Res 2013;15:R2.

25. Pike LR, Singleton DC, Buffa F, Abramczyk O, Phadwal K, Li JL, et al. Transcriptional up-regulation of ULK1 by ATF4 contributes 
to cancer cell survival. Biochem J 2013:449:389-400.

26. Clarke HJ, Chambers JE, Liniker E, Marciniak SJ. Endoplasmic Reticulum Stress in Malignancy. Cancer Cell 2014:25:563-73.

27. Moenner M, Pluquet O, Bouchecareilh M, Chevet E. Integrated endoplasmic reticulum stress responses in cancer. Cancer Res 2007:67:10631-4.

28. Rosati E, Sabatini R, Rampino G, De Falco F, Di Ianni M, Falzetti $\mathrm{F}$, et al. Novel targets for endoplasmic reticulum stress-induced apoptosis in B-CLL. Blood 2010;116:2713-23.

29. Kim I, Xu W, Reed JC. Cell death and endoplasmic reticulum stress: disease relevance and therapeutic opportunities. Nat Rev Drug Discov 2008;7:1013-30.

30. Hetz C, Bernasconi P, Fisher J, Lee AH, Bassik MC, Antonsson B, et al. Proapoptotic BAX and BAK modulate the unfolded protein response by a direct interaction with IRE1alpha. Science 2006; 312:572-6.

31. Zhao X, Ayer RE, Davis SL, Ames SJ, Florence B, Torchinsky C, et al. Apoptosis factor EI24/PIG8 is a novel endoplasmic reticulum-localized Bcl-2-binding protein which is associated with suppression of breast cancer invasiveness. Cancer Res 2005;65: 2125-9.

32. Puthalakath H, O'Reilly LA, Gunn P, Lee L, Kelly PN, Huntington $\mathrm{ND}$, et al. ER stress triggers apoptosis by activating BH3-only protein Bim. Cell 2007;129:1337-49.

33. Dalton LE, Clarke HJ, Knight J, Lawson MH, Wason J, Lomas DA, et al. The endoplasmic reticulum stress marker $\mathrm{CHOP}$ predicts survival in malignant mesothelioma. Br J Cancer 2013;108: 1340-7.

34. Huber AL, Lebeau J, Guillaumot P, Petrilli V, Malek M, Chilloux J, et al. p58(IPK)-mediated attenuation of the proapoptotic PERK-CHOP pathway allows malignant progression upon low glucose. Mol Cell 2013;49:1049-59.

35. Marciniak SJ, Yun CY, Oyadomari S, Novoa I, Zhang Y, Jungreis $\mathrm{R}$, et al. CHOP induces death by promoting protein synthesis and oxidation in the stressed endoplasmic reticulum. Genes Dev 2004; 18:3066-77.

36. Han J, Back SH, Hur J, Lin YH, Gildersleeve R, Shan J, et al. ER-stress-induced transcriptional regulation increases protein synthesis leading to cell death. Nat Cell Biol 2013;15:481-90.

37. Zinszner H, Kuroda M, Wang X, Batchvarova N, Lightfoot RT, Remotti $\mathrm{H}$, et al. CHOP is implicated in programmed cell death in response to impaired function of the endoplasmic reticulum. Genes Dev 1998;12:982-95.

38. Dong D, Stapleton C, Luo B, Xiong S, Ye W, Zhang Y, et al. A critical role for GRP78/BiP in the tumor microenvironment for neovascularization during tumor growth and metastasis. Cancer Res 2011;71:2848-57.

39. Mahadevan NR, Zanetti M. Tumor stress inside out: cell-extrinsic effects of the unfolded protein response in tumor cells modulate the immunological landscape of the tumor microenvironment. J Immunol 2011;187:4403-9.

40. Szegezdi E, Logue SE, Gorman AM, Samali A. Mediators of endoplasmic reticulum stress-induced apoptosis. EMBO Rep 2006; 7:880-5.

41. Shi Y, Vattem KM, Sood R, An J, Liang J, Stramm L, et al. Identification and characterization of pancreatic eukaryotic initiation factor 2 alpha-subunit kinase, PEK, involved in translational control. Mol Cell Biol 1998;18:7499-509.

42. Harding HP, Novoa I, Zhang Y, Zeng H, Wek R, Schapira M, et al.
Regulated translation initiation controls stress-induced gene expression in mammalian cells. Mol Cell 2000;6:1099-108.

43. Scheuner D, Song B, McEwen E, Liu C, Laybutt R, Gillespie P, et al. Translational control is required for the unfolded protein response and in vivo glucose homeostasis. Mol Cell 2001;7:116576.

44. Schindler AJ, Schekman R. In vitro reconstitution of ER-stress induced ATF6 transport in COPII vesicles. Proc Natl Acad Sci USA 2009;106:17775-80.

45. Lee AH, Iwakoshi NN, Anderson KC, Glimcher LH. Proteasome inhibitors disrupt the unfolded protein response in myeloma cells. Proc Natl Acad Sci USA 2003; 100:9946-51.

46. Acosta-Alvear D, Zhou Y, Blais A, Tsikitis M, Lents NH, Arias C, et al. XBP1 controls diverse cell type- and condition-specific transcriptional regulatory networks. Mol Cell 2007;27:53-66.

47. Vandewynckel YP, Laukens D, Geerts A, Bogaerts E, Paridaens A, Verhelst $\mathrm{X}$, et al. The paradox of the unfolded protein response in cancer. Anticancer Res 2013;33:4683-94.

48. Allavena P, Sica A, Garlanda C, Mantovani A. The Yin-Yang of tumor-associated macrophages in neoplastic progression and immune surveillance. Immunol Rev 2008;222:155-61.

49. Mahadevan NR, Rodvold J, Sepulveda H, Rossi S, Drew AF, Zanetti M. Transmission of endoplasmic reticulum stress and pro-inflammation from tumor cells to myeloid cells. Proc Natl Acad Sci USA 2011;108:6561-6.

50. Hung JH, Su IJ, Lei HY, Wang HC, Lin WC, Chang WT, et al. Endoplasmic reticulum stress stimulates the expression of cyclooxygenase-2 through activation of NF-kappaB and pp38 mitogen-activated protein kinase. J Biol Chem 2004;279:46384-92.

51. Park SH, Choi HJ, Yang H, Do KH, Kim J, Lee DW, et al. Endoplasmic reticulum stress-activated C/EBP homologous protein enhances nuclear factor-kappaB signals via repression of peroxisome proliferator-activated receptor gamma. J Biol Chem 2010;285:35330-9.

52. Nakagawa T, Zhu H, Morishima N, Li E, Xu J, Yankner BA, et al. Caspase-12 mediates endoplasmic-reticulum-specific apoptosis and cytotoxicity by amyloid-beta. Nature 2000;403:98-103.

53. Katanasaka Y, Ishii T, Asai T, Naitou H, Maeda N, Koizumi F, et al. Cancer antineovascular therapy with liposome drug delivery systems targeted to BiP/GRP78. Int J Cancer 2010;127:2685-98.

54. O'Reilly MS, Holmgren L, Chen C, Folkman J. Angiostatin induces and sustains dormancy of human primary tumors in mice. Nat Med 1996;2:689-92.

55. Aguirre-Ghiso JA, Estrada Y, Liu D, Ossowski L. ERK(MAPK) activity as a determinant of tumor growth and dormancy; regulation by p38(SAPK). Cancer Res 2003;63:1684-95.

56. Ranganathan AC, Zhang L, Adam AP, Aguirre-Ghiso JA. Functional coupling of p38-induced up-regulation of $\mathrm{BiP}$ and activation of RNA-dependent protein kinase-like endoplasmic reticulum kinase to drug resistance of dormant carcinoma cells. Cancer Res 2006;66:1702-11.

57. Li Z, Li Z. Glucose regulated protein 78: a critical link between tumor microenvironment and cancer hallmarks. Biochim Biophys Acta 2012;1826:13-22.

58. Shuda M, Kondoh N, Imazeki N, Tanaka K, Okada T, Mori K, et al. Activation of the ATF6, XBP1 and grp78 genes in human hepatocellular carcinoma: a possible involvement of the ER stress pathway in hepatocarcinogenesis. J Hepatol 2003;38:605-14.

59. Song MS, Park YK, Lee JH, Park K. Induction of glucose-regulated 
protein 78 by chronic hypoxia in human gastric tumor cells through a protein kinase C-epsilon/ERK/AP-1 signaling cascade. Cancer Res 2001;61:8322-30.

60. Zorzi E, Bonvini P. Inducible hsp70 in the regulation of cancer cell survival: analysis of chaperone induction, expression and activity. Cancers (Basel) 2011;3:3921-56.

61. Kern J, Untergasser G, Zenzmaier C, Sarg B, Gastl G, Gunsilius E, et al. GRP-78 secreted by tumor cells blocks the antiangiogenic activity of bortezomib. Blood 2009;114:3960-7.

62. Miao YR, Eckhardt BL, Cao Y, Pasqualini R, Argani P, Arap W, et al. Inhibition of established micrometastases by targeted drug delivery via cell surface-associated GRP78. Clin Cancer Res 2013; 19:2107-16.

63. Dong D, Ni M, Li J, Xiong S, Ye W, Virrey JJ, et al. Critical role of the stress chaperone GRP78/BiP in tumor proliferation, survival, and tumor angiogenesis in transgene-induced mammary tumor development. Cancer Res 2008;68:498-505.

64. Fu Y, Li J, Lee AS. GRP78/BiP inhibits endoplasmic reticulum BIK and protects human breast cancer cells against estrogen starvation-induced apoptosis. Cancer Res 2007;67:3734-40.

65. Lee HK, Xiang C, Cazacu S, Finniss S, Kazimirsky G, Lemke N, et al. GRP78 is overexpressed in glioblastomas and regulates glioma cell growth and apoptosis. Neuro Oncol 2008;10:236-43.

66. Lee E, Nichols P, Spicer D, Groshen S, Yu MC, Lee AS. GRP78 as a novel predictor of responsiveness to chemotherapy in breast cancer. Cancer Res 2006;66:7849-53.

67. Daneshmand S, Quek ML, Lin E, Lee C, Cote RJ, Hawes D, et al. Glucose-regulated protein GRP78 is up-regulated in prostate cancer and correlates with recurrence and survival. Hum Pathol 2007:38:1547-52.

68. Zheng HC, Takahashi H, Li XH, Hara T, Masuda S, Guan YF, et al. Overexpression of GRP78 and GRP94 are markers for aggressive behavior and poor prognosis in gastric carcinomas. Hum Pathol 2008;39:1042-9.

69. Pootrakul L, Datar RH, Shi SR, Cai J, Hawes D, Groshen SG, et al. Expression of stress response protein Grp78 is associated with the development of castration-resistant prostate cancer. Clin Cancer Res 2006;12:5987-93.

70. Zhuang L, Scolyer RA, Lee CS, McCarthy SW, Cooper WA, Zhang $\mathrm{XD}$, et al. Expression of glucose-regulated stress protein GRP78 is related to progression of melanoma. Histopathology 2009:54: 462-70.

71. Fu Y, Wey S, Wang M, Ye R, Liao CP, Roy-Burman P, et al. Pten null prostate tumorigenesis and AKT activation are blocked by targeted knockout of ER chaperone GRP78/BiP in prostate epithelium. Proc Natl Acad Sci USA 2008; 105:19444-9.

72. Steelman LS, Chappell WH, Abrams SL, Kempf RC, Long J, Laidler P, et al. Roles of the Raf/MEK/ERK and PI3K/PTEN/Akt/ mTOR pathways in controlling growth and sensitivity to therapy-implications for cancer and aging. Aging (Albany NY) 2011; 3:192-222.

73. Su R, Li Z, Li H, Song H, Bao C, Wei J, et al. Grp78 promotes the invasion of hepatocellular carcinoma. BMC Cancer 2010;10:20.

74. Tang H, Kerins DM, Hao Q, Inagami T, Vaughan DE. The urokinase-type plasminogen activator receptor mediates tyrosine phosphorylation of focal adhesion proteins and activation of mitogen-activated protein kinase in cultured endothelial cells. J Biol Chem 1998;273:18268-72.

75. Grkovic S, O'Reilly VC, Han S, Hong M, Baxter RC, Firth SM.
IGFBP-3 binds GRP78, stimulates autophagy and promotes the survival of breast cancer cells exposed to adverse microenvironments. Oncogene 2013;32:2412-20.

76. Tsutsumi S, Namba T, Tanaka KI, Arai Y, Ishihara T, Aburaya M, et al. Celecoxib upregulates endoplasmic reticulum chaperones that inhibit celecoxib-induced apoptosis in human gastric cells. Oncogene 2006;25:1018-29.

77. Zu K, Bihani T, Lin A, Park YM, Mori K, Ip C. Enhanced selenium effect on growth arrest by BiP/GRP78 knockdown in p53-null human prostate cancer cells. Oncogene 2006;25:54654.

78. Saito S, Furuno A, Sakurai J, Sakamoto A, Park HR, Shin-Ya K, et al. Chemical genomics identifies the unfolded protein response as a target for selective cancer cell killing during glucose deprivation. Cancer Res 2009;69:4225-34.

79. Backer JM, Krivoshein AV, Hamby CV, Pizzonia J, Gilbert KS, Ray YS, et al. Chaperone-targeting cytotoxin and endoplasmic reticulum stress-inducing drug synergize to kill cancer cells. Neoplasia 2009;11:1165-73.

80. Paton AW, Beddoe T, Thorpe CM, Whisstock JC, Wilce MC, Rossjohn J, et al. AB5 subtilase cytotoxin inactivates the endoplasmic reticulum chaperone BiP. Nature 2006:443:548-52.

81. Arap MA, Lahdenranta J, Mintz PJ, Hajitou A, Sarkis AS, Arap W, et al. Cell surface expression of the stress response chaperone GRP78 enables tumor targeting by circulating ligands. Cancer Cell 2004:6:275-84.

82. Ni M, Zhang Y, Lee AS. Beyond the endoplasmic reticulum: atypical GRP78 in cell viability, signalling and therapeutic targeting. Biochem J 2011;434:181-8.

83. Sun FC, Wei S, Li CW, Chang YS, Chao CC, Lai YK. Localization of GRP78 to mitochondria under the unfolded protein response. Biochem J 2006;396:31-9.

84. Bi M, Naczki C, Koritzinsky M, Fels D, Blais J, Hu N, et al. ER stress-regulated translation increases tolerance to extreme hypoxia and promotes tumor growth. EMBO J 2005;24:3470-81.

85. Firczuk M, Gabrysiak M, Barankiewicz J, Domagala A, Nowis D, Kujawa M, et al. GRP78-targeting subtilase cytotoxin sensitizes cancer cells to photodynamic therapy. Cell Death Dis 2013:4: e741.

86. Brunelle JK, Bell EL, Quesada NM, Vercauteren K, Tiranti V, Zeviani $\mathrm{M}$, et al. Oxygen sensing requires mitochondrial ROS but not oxidative phosphorylation. Cell Metab 2005;1:409-14.

87. Guzy RD, Hoyos B, Robin E, Chen H, Liu L, Mansfield KD, et al. Mitochondrial complex III is required for hypoxia-induced ROS production and cellular oxygen sensing. Cell Metab 2005;1:4018.

88. Harding HP, Zhang Y, Ron D. Protein translation and folding are coupled by an endoplasmic-reticulum-resident kinase. Nature 1999;397:271-4.

89. Cullinan SB, Zhang D, Hannink M, Arvisais E, Kaufman RJ, Diehl JA. Nrf2 is a direct PERK substrate and effector of PERK-dependent cell survival. Mol Cell Biol 2003;23:7198-209.

90. Harding HP, Zhang Y, Bertolotti A, Zeng H, Ron D. Perk is essential for translational regulation and cell survival during the unfolded protein response. Mol Cell 2000;5:897-904.

91. Vattem KM, Wek RC. Reinitiation involving upstream ORFs regulates ATF4 mRNA translation in mammalian cells. Proc Natl Acad Sci USA 2004;101:11269-74.

92. Alam J, Stewart D, Touchard C, Boinapally S, Choi AM, Cook JL. 
Nrf2, a Cap'n'Collar transcription factor, regulates induction of the heme oxygenase-1 gene. J Biol Chem 1999:274:26071-8.

93. Hayes JD, Chanas SA, Henderson CJ, McMahon M, Sun C, Moffat GJ, et al. The Nrf2 transcription factor contributes both to the basal expression of glutathione S-transferases in mouse liver and to their induction by the chemopreventive synthetic antioxidants, butylated hydroxyanisole and ethoxyquin. Biochem Soc Trans 2000;28:33-41.

94. Itoh K, Chiba T, Takahashi S, Ishii T, Igarashi K, Katoh Y, et al. An Nrf2/small Maf heterodimer mediates the induction of phase II detoxifying enzyme genes through antioxidant response elements. Biochem Biophys Res Commun 1997:236: 313-22.

95. Wild AC, Moinova HR, Mulcahy RT. Regulation of gamma-glutamylcysteine synthetase subunit gene expression by the transcription factor Nrf2. J Biol Chem 1999:274:33627-36.

96. Bobrovnikova-Marjon E, Grigoriadou C, Pytel D, Zhang F, Ye J, Koumenis C, et al. PERK promotes cancer cell proliferation and tumor growth by limiting oxidative DNA damage. Oncogene 2010;29:3881-95.

97. Mimura N, Fulciniti M, Gorgun G, Tai YT, Cirstea D, Santo L, et al. Blockade of XBP1 splicing by inhibition of IRE1alpha is a promising therapeutic option in multiple myeloma. Blood 2012; 119:5772-81.

98. Hollien J, Weissman JS. Decay of endoplasmic reticulum- localized mRNAs during the unfolded protein response. Science 2006:313:104-7.

99. Urano F, Wang X, Bertolotti A, Zhang Y, Chung P, Harding HP, et al. Coupling of stress in the ER to activation of JNK protein kinases by transmembrane protein kinase IRE1. Science 2000;287: 664-6.

100. Yang W, Tiffany-Castiglioni E, Koh HC, Son IH. Paraquat activates the IRE1/ASK1/JNK cascade associated with apoptosis in human neuroblastoma SH-SY5Y cells. Toxicol Lett 2009;191:20310.

101. Nishitoh H, Matsuzawa A, Tobiume K, Saegusa K, Takeda K, Inoue $\mathrm{K}$, et al. ASK1 is essential for endoplasmic reticulum stress-induced neuronal cell death triggered by expanded polyglutamine repeats. Genes Dev 2002;16:1345-55.

102. Wu J, Kaufman RJ. From acute ER stress to physiological roles of the Unfolded Protein Response. Cell Death Differ 2006;13:37484.

103. Romero-Ramirez L, Cao H, Nelson D, Hammond E, Lee AH, Yoshida $\mathrm{H}$, et al. XBP1 is essential for survival under hypoxic conditions and is required for tumor growth. Cancer Res 2004; 64:5943-7.

104. Chen Y, Feldman DE, Deng C, Brown JA, De Giacomo AF, Gaw $\mathrm{AF}$, et al. Identification of mitogen-activated protein kinase signaling pathways that confer resistance to endoplasmic reticulum stress in Saccharomyces cerevisiae. Mol Cancer Res 2005; 3:669-77.

105. Romero-Ramirez L, Cao H, Regalado MP, Kambham N, Siemann $\mathrm{D}, \mathrm{Kim} \mathrm{JJ}$, et al. $\mathrm{X}$ box-binding protein 1 regulates angiogenesis in human pancreatic adenocarcinomas. Transl Oncol 2009;2: 31-8.

106. Davies MP, Barraclough DL, Stewart C, Joyce KA, Eccles RM, Barraclough $\mathrm{R}$, et al. Expression and splicing of the unfolded protein response gene XBP-1 are significantly associated with clinical outcome of endocrine-treated breast cancer. Int J Cancer
2008; 123:85-8

107. Zhong Y, Li J, Wang JJ, Chen C, Tran JT, Saadi A, et al. X-box binding protein 1 is essential for the anti-oxidant defense and cell survival in the retinal pigment epithelium. PLoS One 2012; 7:e38616.

108. Han D, Lerner AG, Vande Walle L, Upton JP, Xu W, Hagen A, et al. IRE1alpha kinase activation modes control alternate endoribonuclease outputs to determine divergent cell fates. Cell 2009:138:562-75.

109. Scriven P, Coulson S, Haines R, Balasubramanian S, Cross S, Wyld L. Activation and clinical significance of the unfolded protein response in breast cancer. Br J Cancer 2009;101:1692-8.

110. Li X, Zhang $\mathrm{K}, \mathrm{Li} Z$. Unfolded protein response in cancer: the physician's perspective. J Hematol Oncol 2011;4:8.

111. Richardson PG, Mitsiades C, Hideshima T, Anderson KC. Bortezomib: proteasome inhibition as an effective anticancer therapy. Annu Rev Med 2006;57:33-47.

112. Richardson PG, Barlogie B, Berenson J, Singhal S, Jagannath S, Irwin D, et al. A phase 2 study of bortezomib in relapsed, refractory myeloma. N Engl J Med 2003;348:2609-17.

113. Adams J, Palombella VJ, Sausville EA, Johnson J, Destree A, Lazarus DD, et al. Proteasome inhibitors: a novel class of potent and effective antitumor agents. Cancer Res 1999;59:2615-22.

114. Ling YH, Liebes L, Jiang JD, Holland JF, Elliott PJ, Adams J, et al. Mechanisms of proteasome inhibitor PS-341-induced G(2)-Mphase arrest and apoptosis in human non-small cell lung cancer cell lines. Clin Cancer Res 2003:9:1145-54.

115. Pham LV, Tamayo AT, Yoshimura LC, Lo P, Ford RJ. Inhibition of constitutive NF-kappa B activation in mantle cell lymphoma B cells leads to induction of cell cycle arrest and apoptosis. J Immunol 2003;171:88-95.

116. Fels DR, Ye J, Segan AT, Kridel SJ, Spiotto M, Olson M, et al. Preferential cytotoxicity of bortezomib toward hypoxic tumor cells via overactivation of endoplasmic reticulum stress pathways. Cancer Res 2008;68:9323-30.

117. Nawrocki ST, Carew JS, Dunner K, Jr., Boise LH, Chiao PJ, Huang P, et al. Bortezomib inhibits PKR-like endoplasmic reticulum (ER) kinase and induces apoptosis via ER stress in human pancreatic cancer cells. Cancer Res 2005;65:11510-9.

118. Tirosh B, Iwakoshi NN, Glimcher LH, Ploegh HL. Rapid turnover of unspliced Xbp- 1 as a factor that modulates the unfolded protein response. J Biol Chem 2006;281:5852-60.

119. Wang Q, Mora-Jensen H, Weniger MA, Perez-Galan P, Wolford C, Hai $\mathrm{T}$, et al. ERAD inhibitors integrate ER stress with an epigenetic mechanism to activate BH3-only protein NOXA in cancer cells. Proc Natl Acad Sci USA 2009;106:2200-5.

120. Hoseki J, Ushioda R, Nagata K. Mechanism and components of endoplasmic reticulum-associated degradation. J Biochem 2010; 147:19-25.

121. Michelet C, Chapplain JM, Petsaris O, Arvieux C, Ruffault A, Lotteau $\mathrm{V}$, et al. Differential effect of ritonavir and indinavir on immune response to hepatitis C virus in HIV-1 infected patients. AIDS 1999;13:1995-6.

122. Li J, Buchner J. Structure, function and regulation of the hsp90 machinery. Biomed J 2013;36:106-17.

123. Davenport EL, Moore HE, Dunlop AS, Sharp SY, Workman P, Morgan GJ, et al. Heat shock protein inhibition is associated with activation of the unfolded protein response pathway in myeloma plasma cells. Blood 2007;110:2641-9. 
124. Marcu MG, Doyle M, Bertolotti A, Ron D, Hendershot L, Neckers L. Heat shock protein 90 modulates the unfolded protein response by stabilizing IRE1alpha. Mol Cell Biol 2002;22:8506-13.

125. Boya P, Cohen I, Zamzami N, Vieira HL, Kroemer G. Endoplasmic reticulum stress-induced cell death requires mitochondrial membrane permeabilization. Cell Death Differ 2002;9:465-7.

126. Carew JS, Nawrocki ST, Krupnik YV, Dunner K Jr, McConkey DJ, Keating MJ, et al. Targeting endoplasmic reticulum protein transport: a novel strategy to kill malignant B cells and overcome fludarabine resistance in CLL. Blood 2006;107:222-31.

127. Guo H, Tittle TV, Allen H, Maziarz RT. Brefeldin A-mediated apoptosis requires the activation of caspases and is inhibited by Bcl-2. Exp Cell Res 1998;245:57-68.

128. Salles FT, Hespanhol AM, Jaeger RG, Marques MM. Brefeldin-A induces apoptosis in human adenoid cystic carcinoma cultured cells. Oral Oncol 2004:40:585-90.

129. Shao ZM, Nguyen M, Alpaugh ML, O'Connell JT, Barsky SH. The human myoepithelial cell exerts antiproliferative effects on breast carcinoma cells characterized by p21WAF1/CIP1 induction, G2/M arrest, and apoptosis. Exp Cell Res 1998;241:394-403.

130. Wallen E, Sellers RG, Peehl DM. Brefeldin A induces p53-independent apoptosis in primary cultures of human prostatic cancer cells. J Urol 2000;164(3 Pt 1):836-41.

131. Wlodkowic D, Skommer J, Pelkonen J. Brefeldin A triggers apoptosis associated with mitochondrial breach and enhances HA14-1- and anti-Fas-mediated cell killing in follicular lymphoma cells. Leuk Res 2007;31:1687-700.

132. Pyrko P, Schonthal AH, Hofman FM, Chen TC, Lee AS. The unfolded protein response regulator GRP78/BiP as a novel target for increasing chemosensitivity in malignant gliomas. Cancer Res 2007;67:9809-16.

133. Park HR, Tomida A, Sato S, Tsukumo Y, Yun J, Yamori T, et al. Effect on tumor cells of blocking survival response to glucose deprivation. J Natl Cancer Inst 2004:96:1300-10.

134. Martin S, Lamb HK, Brady C, Lefkove B, Bonner MY, Thompson $\mathrm{P}$, et al. Inducing apoptosis of cancer cells using small-molecule plant compounds that bind to GRP78. Br J Cancer 2013;109:43343.

135. Cross BC, Bond PJ, Sadowski PG, Jha BK, Zak J, Goodman JM, et al. The molecular basis for selective inhibition of unconventional mRNA splicing by an IRE1-binding small molecule. Proc Natl Acad Sci USA 2012;109:E869-78.

136. Papandreou I, Denko NC, Olson M, Van Melckebeke H, Lust S, Tam A, et al. Identification of an Irelalpha endonuclease specific inhibitor with cytotoxic activity against human multiple myeloma. Blood 2011;117:1311-4.

137. Volkmann K, Lucas JL, Vuga D, Wang X, Brumm D, Stiles C, et al. Potent and selective inhibitors of the inositol-requiring enzyme 1 endoribonuclease. J Biol Chem 2011;286:12743-55.

138. Suh DH, Kim MK, Kim HS, Chung HH, Song YS. Unfolded protein response to autophagy as a promising druggable target for anticancer therapy. Ann N Y Acad Sci 2012;1271:20-32.

139. Atkins C, Liu Q, Minthorn E, Zhang SY, Figueroa DJ, Moss K, et al. Characterization of a novel PERK kinase inhibitor with antitumor and antiangiogenic activity. Cancer Res 2013;73:19932002.

140. Salazar M, Carracedo A, Salanueva IJ, Hernandez-Tiedra S, Lorente M, Egia A, et al. Cannabinoid action induces autophagy-mediated cell death through stimulation of ER stress in hu- man glioma cells. J Clin Invest 2009;119:1359-72.

141. Liu BQ, Gao YY, Niu XF, Xie JS, Meng X, Guan Y, et al. Implication of unfolded protein response in resveratrol-induced inhibition of K562 cell proliferation. Biochem Biophys Res Commun 2010;391:778-82.

142. Townsend DM, Manevich Y, He L, Xiong Y, Bowers RR Jr, Hutchens $\mathrm{S}$, et al. Nitrosative stress-induced s-glutathionylation of protein disulfide isomerase leads to activation of the unfolded protein response. Cancer Res 2009;69:7626-34.

143. Déry MA, Jodoin J, Ursini-Siegel J, Aleynikova O, Ferrario C, Hassan S, et al. Endoplasmic reticulum stress induces PRNP prion protein gene expression in breast cancer. Breast Cancer Res 2013;15:R22

144. Zhang Y, Tseng CC, Tsai YL, Fu X, Schiff R, Lee AS. Cancer cells resistant to therapy promote cell surface relocalization of GRP78 which complexes with PI3K and enhances $\mathrm{PI}(3,4,5) \mathrm{P} 3$ production. PLoS One 2013;8:e80071.

145. Gupta S, McGrath B, Cavener DR. PERK regulates the proliferation and development of insulin-secreting beta-cell tumors in the endocrine pancreas of mice. PLoS One 2009;4:e8008.

146. Overley-Adamson B, Artlett CM, Stephens C, Sassi-Gaha S, Weis $\mathrm{RD}$, Thacker JD. Targeting the unfolded protein response, XBP1, and the NLRP3 inflammasome in fibrosis and cancer. Cancer Biol Ther 2014;15:452-62.

147. Mahoney DJ, Lefebvre C, Allan K, Brun J, Sanaei CA, Baird S, et al. Virus-tumor interactome screen reveals ER stress response can reprogram resistant cancers for oncolytic virus-triggered caspase-2 cell death. Cancer Cell 2011:20:443-56.

148. Li Z, Zhang L, Zhao Y, Li H, Xiao H, Fu R, et al. Cell-surface GRP78 facilitates colorectal cancer cell migration and invasion. Int J Biochem Cell Biol 2013;45:987-94.

149. Delie F, Petignat P, Cohen M. GRP78 Protein Expression in Ovarian Cancer Patients and Perspectives for a Drug-Targeting Approach. J Oncol 2012;2012:468615.

150. Garg AD, Nowis D, Golab J, Vandenabeele P, Krysko DV, Agostinis P. Immunogenic cell death, DAMPs and anticancer therapeutics: an emerging amalgamation. Biochim Biophys Acta 2010;1805:53-71.

151. Mujtaba T, Dou QP. Advances in the understanding of mechanisms and therapeutic use of bortezomib. Discov Med 2011;12: 471-80.

152. Spisek R, Charalambous A, Mazumder A, Vesole DH, Jagannath S, Dhodapkar MV. Bortezomib enhances dendritic cell (DC)mediated induction of immunity to human myeloma via exposure of cell surface heat shock protein 90 on dying tumor cells: therapeutic implications. Blood 2007;109:4839-45.

153. Hanson BE, Vesole DH. Retaspimycin hydrochloride (IPI-504): a novel heat shock protein inhibitor as an anticancer agent. Expert Opin Investig Drugs 2009;18:1375-83.

154. Bachleitner-Hofmann T, Sun MY, Chen CT, Liska D, Zeng Z, Viale A, et al. Antitumor activity of SNX-2112, a synthetic heat shock protein-90 inhibitor, in MET-amplified tumor cells with or without resistance to selective MET Inhibition. Clin Cancer Res 2011;17:122-33.

155. Suraweera A, Münch C, Hanssum A, Bertolotti A. Failure of amino acid homeostasis causes cell death following proteasome inhibition. Mol Cell 2012;48:242-53.

156. Kardosh A, Golden EB, Pyrko P, Uddin J, Hofman FM, Chen TC, et al. Aggravated endoplasmic reticulum stress as a basis for en- 
hanced glioblastoma cell killing by bortezomib in combination with celecoxib or its non-coxib analogue, 2,5-dimethyl-celecoxib. Cancer Res 2008;68:843-51.
157. Lore K, Andersson J. Detection of cytokine- and chemokine- expressing cells at the single cell level. Methods Mol Biol 2004; 249:201-18. 